\title{
Morphological and anatomical studies on some dicot plant species collected from East Egypt desert
}

Tawab.S.A., Wafaa, M. Said, Reem, M.S.Sayed and Fatma, A. Morsi

Botany department, Faculty of women for Arts, Science and Education, Ain Shams University.

\begin{abstract}
:
The present study included the whole plant morphology and leaf blade anatomy of four dicot species belonging to four families; Apocynaceae, Geraniaceae, Plantagonaceae and Polygonaceae collected from east Egypt desert during three seasons in 2014, 2015 and 2016. Morphologically, the results obtained show annual habit in three species but Cynanchum acutum found as perennial herb, all species have hairy surface. Stem ranged from erect in Plantago ovate and Rumex vesicarius to climbing in Cynanchum acutum and prostrate in Erodium ciconium . Anatomically, the results showed the presence of compact uniseriate epidermis, thick cuticle in all species. Trichomes varied from simple and glandular hairs in Erodium ciconium, glandular in Plantago ovate and Rumex vesicarius and absent in Cynanchum acutum. Multilayers of palisade tissue were found in all species except Cynanchum acutum. Calcium oxalate crystals were found as druses in all taxa except Plantago ovate. From the above results, morphologically as well as anatomically all studied species were found to be adapted to arid envinorment.
\end{abstract}

Keywords: Anatomy, morphology, Apocynaceae, Geraniaceae, Plantagonaceae \& Polygonaceae.

\section{Introduction}

Anatomical and morphological studies are concerned with the internal and external structure of plants. It is an amazing source for proper identification of plant taxa. Xerophytes are the plants which are able to stay alive in an environment with a limited supply of water as compared to hydrophytes and mesophytes where potential evapotranspiration exceeds rainfall for all or part of the growing season. Comus and Philips (2009) stated that xerophytes might be adapted morphologically, anatomically and physiologically to reduce their water loss or store water during long periods of dryness. Parolin (2009) described the plants with such adaptations as xeromorph. Hameed et al. (2008) reported that the flowers of xerophytes usually develop in favorable conditions and they complete their reproduction in very short period of time. Fruits and seeds are protected by very hard coverings and they can remain resting for a long period of time. Anatomically, a number of modifications develop internally in the xeric plants to overcome the water losses. Epidermal cells of xerophytes are small compact single layer with thick cuticle. Fahn (1990) discussed that the arrangement of palisade cells on each side of the lamina while the spongy parenchyma with some intercellular tissue is limited to the area around the veins is a common character found in plants growing in full sun. Cao (2000) concluded that the presence of two or more layers of palisade cells in leaves are the xeromorphic features. Many studies on xerophytes have been made by other scientists (Wahid, 2003; Hussain, 2011 and Hameed et al., 2012). 
The aim of this work was to study the collected plants morphologically, anatomically, evaluate features of adaptation and documents them to be preserved as reference herbarium in botany department, Faculty of women for Arts, Science and Education, Ain Shams University.

Corresponding author: fatma.abdelnaby@women.asu.edu.eg 


\section{Materials and Methods}

\subsection{Sampling and Collection of Plant Specimens}

Fresh and healthy plants of each species (4/species) were collected by Fatma A. Morsi from East Egypt desert in 3 seasons during 2014, 2015 and 2016.

\subsection{Taxonomical Studies}

The proper identification and taxonomy of each species was carried out with the help of available literature (Täckholm, 1974 and Boulos, 1999, 2000, 2002). The identification was confirmed and authenticated in Herbarium of Faculty of Science, Botany department, Ain Shams University.

Table (1): Systematic Classification of studied species.

\begin{tabular}{|l|l|l|l|l|}
\hline \multicolumn{1}{|c|}{ order } & \multicolumn{1}{|c|}{ Family } & \multicolumn{1}{|c|}{ Genus } & \multicolumn{1}{|c|}{ Species } & \\
\hline Gentianales & Apocynaceae & Cynanchum & acutum & Cynanchum acutum L \\
\hline Geraniales & Geraniaceae & Erodium & ciconium & Erodium ciconium (L.) \\
\hline Primulales & Plantagonaceae & Plantago & ovata & Plantago ovate Forssk \\
\hline Caryophyllales & Polygonaceae & Rumex & vesicarius & Rumex vesicarius L \\
\hline
\end{tabular}

\subsection{Morphological and Anatomical Studies:}

According to Täckholm 1974; Boulos, 1999, 2000, 2002 and Pandey (2010), the morphological descriptions as; habit, root, stem, leaves, flowers and fruit was recorded in table (2) and photographed in plate (I). Fresh material of leaf blade was collected to study the anatomical features. The specimens were fixed at least 48 hours in formalin acetic acid alcohol solution F.A.A. (formalin -glacial acetic acid - 70\% alcohol) with the ratio of 5:5: 90 $\mathrm{V} / \mathrm{V}$ and preserved in $70 \%$ alcohol, then dehydrated in ethyl alcohol series, sectioned on a rotary microtome and stained in safranin and fast green, then mounted in canada balsam according to Johansen (1940). The sections were examined with Olympus CX21 light microscope. Anatomical description was listed in table (3) and photographed with Digital microscope eyepiece HiROCAM; type MA88-500 and presented in plate (II) Anatomical terms used relating to Metcalfe and Chalk (1979), Fahn (1990), Esau (2013) and Garces (2013). 


\section{Results and discussion}

Morphological and anatomical studies are the first basic tools to identify and classify plant species, collected species showed existence of a single layer of epidermis, increased thickness layer of cutin as well as the presence of hairs and increased of palisade tissue layers which considered as an adaptation to survive the drought in arid region and complete their life cycle in a short period according to Cao (2000) and Hussain (2011).

Morphologically, Cynuncium acutum is a glabrous perennial twining herb. Leaves are simple, petiolate, exstipulate, opposite, cordate with auriculate base. Flowers are in longpeduncle axillary cymose, corolla is pinkish white. Fruit is follicle, Erodium ciconium is a hairy annual herb with weak procumbent stem, leaves are petiolate, stipulate, small pinnatifid, ovate-deltoid and opposite. Flowers are pedunculate; umbels 3-5 flowered, bisexual, violet. Fruit is schizocarp; mericarps 1-seeded usually with a pit and furrowed beneath the beak. Plantago ovate Forssk is annual herb with short stem. Leaves grey to white, hairy, alternate in rosette, folded lanceolate, with acute apex and entire margin. Inflorescence is simple spike. Peduncles are erect, shorter to longer than leaves, terete, ovoid, very dense. Fruit capsule; 2 seeded, whereas Rumex vesicarius L. is an annual herb. Stem erect and branched from the base. Leaves are fleshy, ovate-deltoid, green and petiolate. Flowers bisexual in racemose inflorescences; pedicels 2-3 flowered, pinkish, wings in fruit membranous, reddish reticulate-veined without marginal nerves. Fruit is nutlet, ovoid, brownish and smooth. The result obtained is congruent with Pandey (2010).

Anatomically, leaf blade of Cynuncium acutum reveals that epidermis is uniseriate tangentially elongated covered with thick and rough cuticle on both surfaces. The mesophyll is dorsiventral type. Palisade mesophyll composed of 1-2 layers occur toward adaxial and abaxial surfaces and spongy tissues situated in between. Mechanical tissue is represented by 7 layers of angular collenchyma which located adaxially and abaxially at the mid rib region. Vascular system represented by large vascular bundle crescent shape in the mid rib region and small vascular bundles in the leaf lamina. The results of present stuy are in agreement with the findings of Abu Ziada, et al. (2016). Cross section of leaf blade of Erodium ciconium showed that epidermis is composed of uniseriate small tangentially compactly arranged cells covered with thick and smooth cuticle on both surface. Trichomes are present as simple unicelluer hair and glandular hair. Crystals are present as druses. The mesophyll is dorsiventral type. palisade cells composed of 2 - 3 layers of columnar cell and interrupted by longitudinal air vacuoles occur toward adaxial surface and There are 2 - 3 layers of spongy cell occur toward abaxial surface; quite loosely arranged with intercellular space. Mechanical tissue is represented by 4-5 layers of angular collenchyma which located abaxially at the mid rib region. Vascular system represented by two vascular bundles in the mid rib region the upper one is smaller than the lower kidney shaped one. Keshavarzi, et al. (2016) studied some accessions of Erodium ciconium and they found that the leaves have mesophyll with dorsiventral type; vascular bundles vary in number and size. They were 1 to 2 in mid rib and simple, glandular hairs were observed. The outline shape of leaf blade of Plantago ovate is deeply crescent, epidermal cells are composed of small uniseriate tangentially cells, coated with thick and rough cuticle. Hypodermal cells composed of 2-3 layers of chlorenchyma cells. Trichomes are present as glandular hair. The mesophyll is differentiated into palisade cells and spongy tissues, the palisade cells occur toward both surface and composed of one layer. Vascular system represented by large conjoint vascular bundle in the central region, and 
small vascular bundle are present. Pascedilla ca, et al. (2016) studied leaf anatomy of Plantago lanceolata. They found that leaves have bifacial type and the epidermis is a single layer of oval - elliptical cells, covered with thick cuticle and calcium oxalate crystals are found as druses. Their results supported the current research finding but Marius-Nicugor Grigore \& Constantin Toma (2008) studied Plantago schwarzenbergiana, they noticed that it has short trichomes located in small depressions; some of these have one-celled gland, others bi- or tri-celled gland and mesophyll consists of a 2-3 layered palisade tissue at the upper epidermis. These results are not in agreement of the present research. Epidermal cells of Rumex vesicarius are composed of uniseriate tangentially compactly arranged cell, coated with thick and rough cuticle on both surface. Crystals are present as druses. Trichomes found a glandular hairs. The mesophyll is dorsiventral type. The palisade cells composed of 2- 3 layers occur toward adaxial and abaxial surface. Mechanical tissue is represented by $3-4$ layers of collenchyma which situated adaxially and abaxially at midrib region. Vascular system represented by 2 large conjoint vascular bundle in the mid rib region and many small vascular bundle in the leaf lamina. The results of present studies are in agreement with Rao et al. (2011) who stated that Rumex vesicarius has single layer epidermis and mesophyll of dorsiventral type which differentiated into upper palisade parenchyma and lower spongy parenchyma. Palisade parenchyma consists of two or three layers of compactly arranged cells in perpendicular to the surface. Spongy parenchyma consists of loosely arranged cells having air filled spaces in between. 


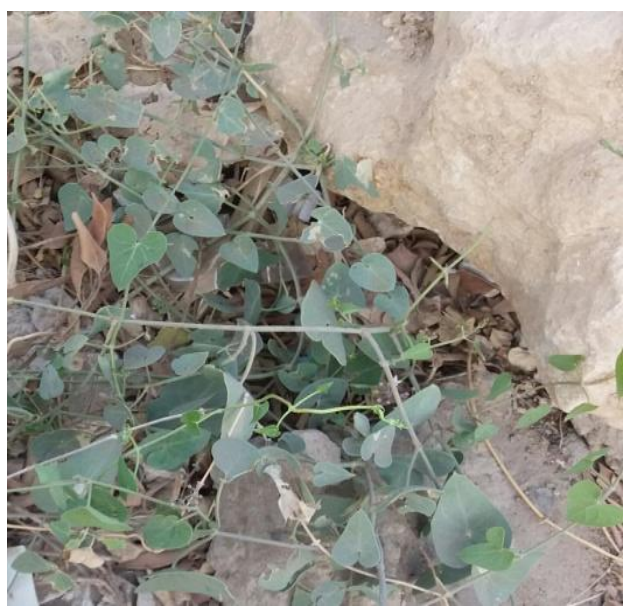

1- Cynanchum acutum L

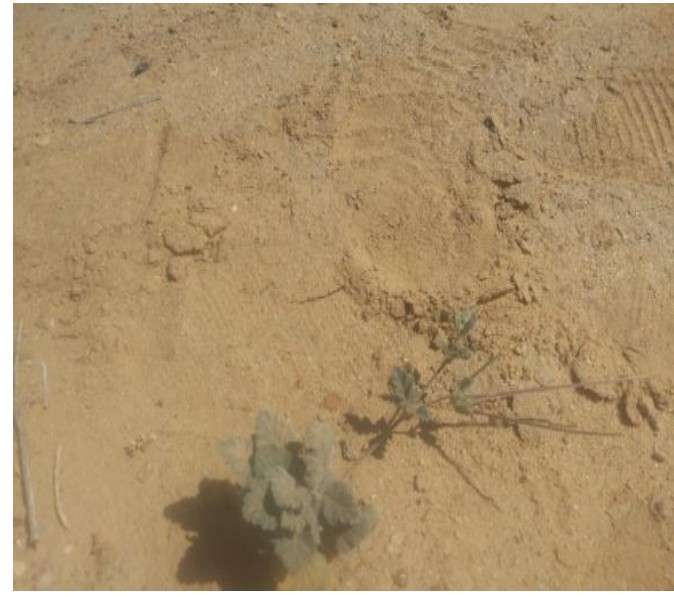

2- Erodium ciconium (L.)

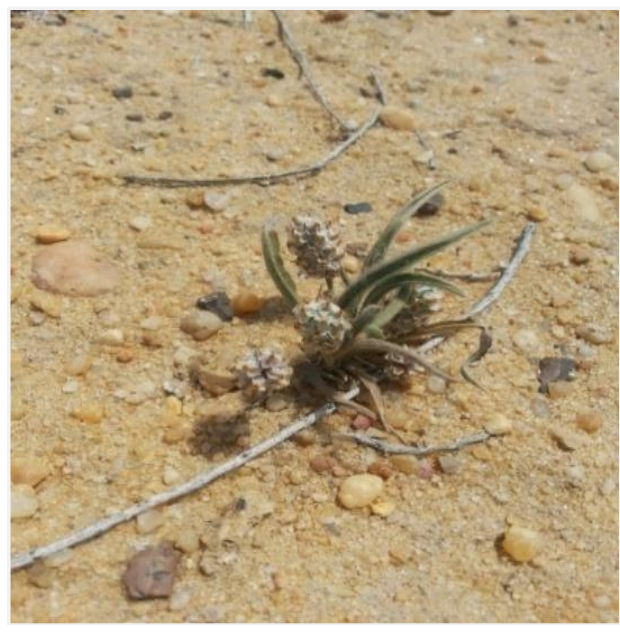

3- Plantago ovate Forssk

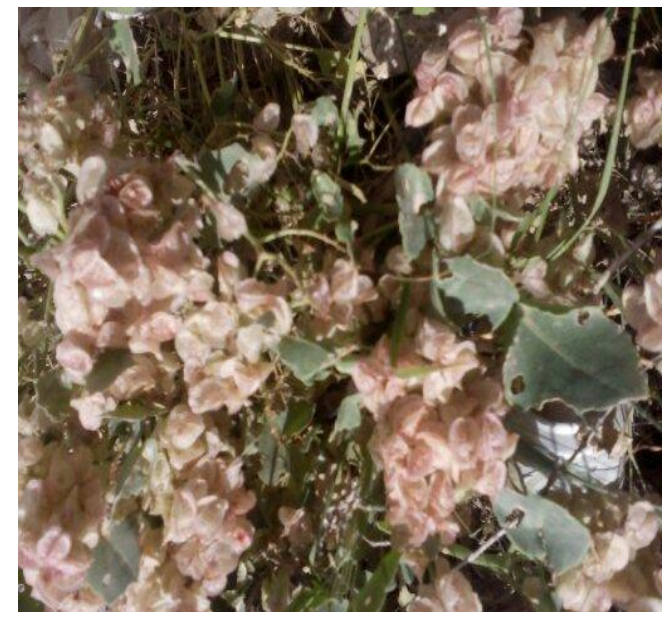

4- Rumex vesicarius L

Plate (I): Morphological Aspects of taxa studied. 


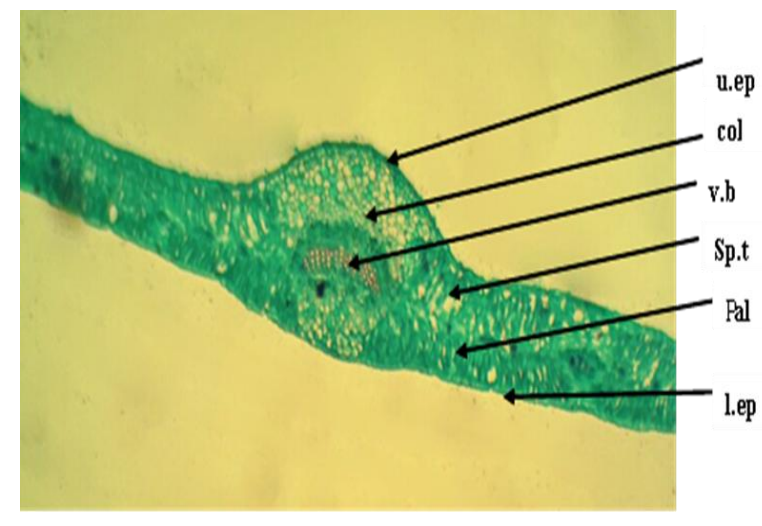

1- Cynanchum acutum L

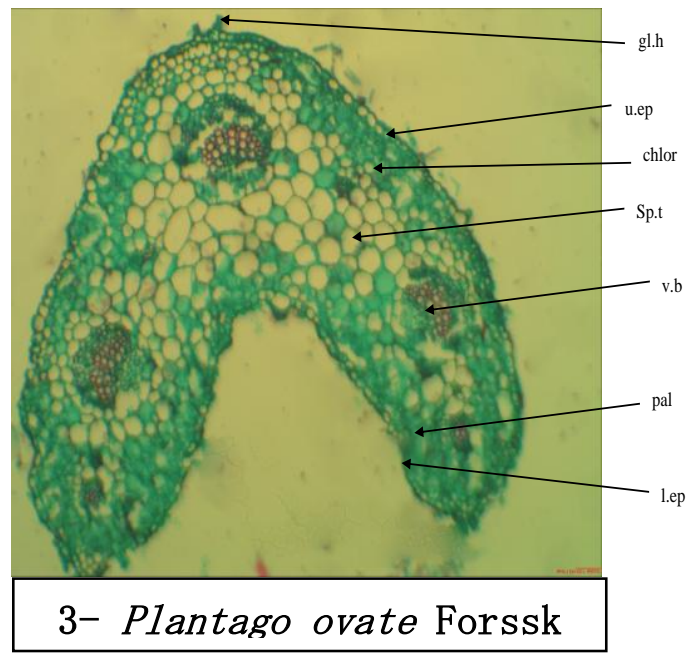

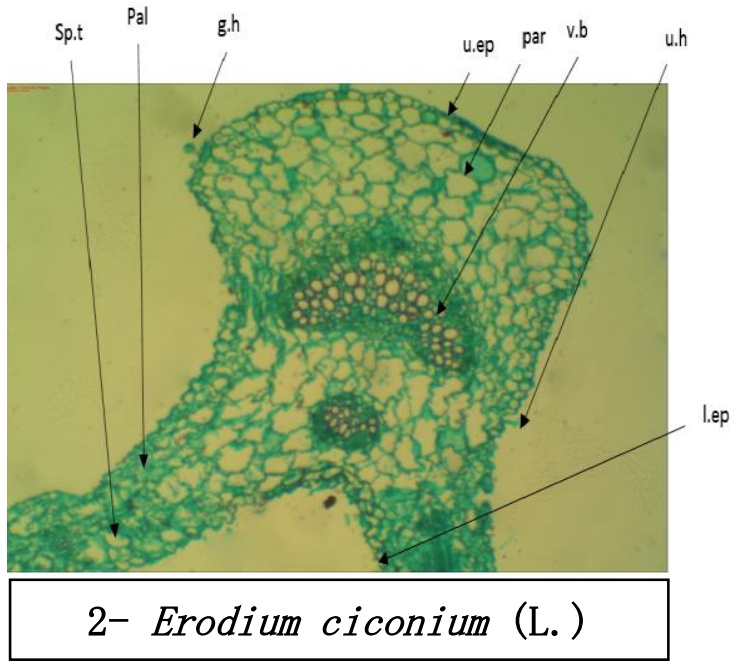

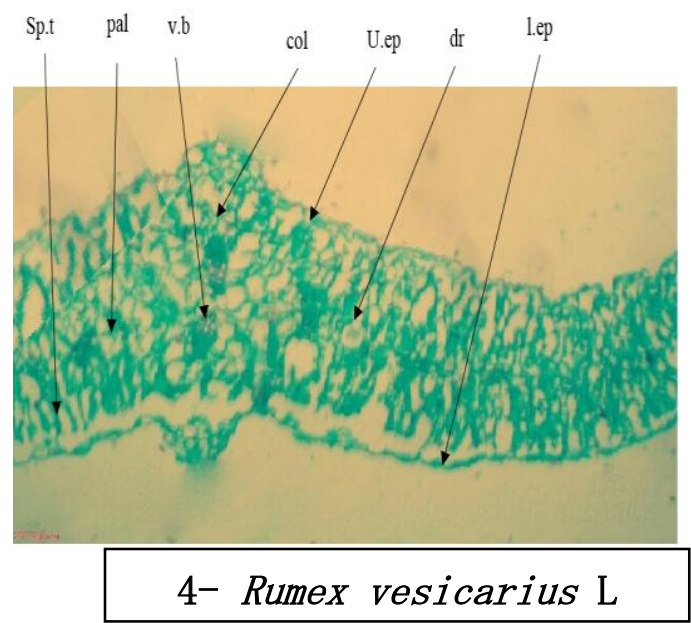

Plate (II): Anatomical Aspects of leaf blades of taxa studied.

T. S of leaf blade where; u.ep, upper epidermis; dr, druses; v.b., vascular bundle; sp.t, spongy tissues ; pal., palisade tissue ;col, collenchyma; par, parenchyma; u.h ,unicellular hair; g.h ,glandular hair ; I.ep, lower epidermis; I.ep, lower epidermis 
Table (2): Description of morphological characters of all taxa studied

\begin{tabular}{|c|c|c|c|c|c|c|c|c|c|c|c|}
\hline$N$ & Plant species & Habit & Stem & & Lea & charact & & & Charac & Infloresc & Fruit \\
\hline v & & $\begin{array}{c}+ \\
\text { Life } \\
\text { form }\end{array}$ & & Type & Apex & $\begin{array}{c}\text { Margi } \\
\mathrm{n}\end{array}$ & $\begin{array}{c}\text { Surfac } \\
\text { e }\end{array}$ & $\begin{array}{l}\text { Leaf } \\
\text { arran } \\
\text { geme } \\
\text { nt }\end{array}$ & $\begin{array}{l}\text { ter } \\
\text { of } \\
\text { petiole }\end{array}$ & $\begin{array}{l}\text { ence } \\
\text { type }\end{array}$ & \\
\hline 1 & $\begin{array}{c}\text { Cynanchum } \\
\text { acutum }\end{array}$ & $\begin{array}{c}\text { Peren } \\
\text { nial } \\
\text { herb }\end{array}$ & $\begin{array}{c}\text { Climb } \\
\text { er }\end{array}$ & $\begin{array}{l}\text { Simple } \\
\text { (cordat } \\
\text { e) }\end{array}$ & Acute & Entire & $\begin{array}{l}\text { Glabr } \\
\text { ous }\end{array}$ & $\begin{array}{l}\text { Oppos } \\
\text { ite }\end{array}$ & $\begin{array}{l}\text { Petiola } \\
\text { te }\end{array}$ & Umbel & Follicle \\
\hline 2 & $\begin{array}{l}\text { Erodium } \\
\text { ciconium }\end{array}$ & $\begin{array}{c}\text { Annua } \\
\text { I } \\
\text { herb }\end{array}$ & $\begin{array}{l}\text { prostr } \\
\text { ate }\end{array}$ & Lobed & $\begin{array}{c}\text { Round } \\
\text { ed }\end{array}$ & $\begin{array}{l}\text { Undul } \\
\text { ate }\end{array}$ & Hairy & $\begin{array}{l}\text { Oppos } \\
\text { ite }\end{array}$ & $\begin{array}{l}\text { Petiola } \\
\text { te }\end{array}$ & Umbel & $\begin{array}{l}\text { Schizoc } \\
\text { arp }\end{array}$ \\
\hline 3 & $\begin{array}{c}\text { Plantago } \\
\text { ovate }\end{array}$ & $\begin{array}{c}\text { Annua } \\
\text { I } \\
\text { herb }\end{array}$ & Erect & $\begin{array}{c}\text { Simple } \\
\text { folded } \\
\text { lanceol } \\
\text { ate }\end{array}$ & Acute & Entire & Hairy & $\begin{array}{l}\text { Altern } \\
\text { ate in } \\
\text { rosett } \\
\mathrm{e}\end{array}$ & Sessile & Spike & Capsule \\
\hline 4 & $\begin{array}{c}\text { Rumex } \\
\text { vesicarius. }\end{array}$ & $\begin{array}{c}\text { Annua } \\
\text { I } \\
\text { herb }\end{array}$ & Erect & Simple & $\begin{array}{c}\text { Obtus } \\
\mathrm{e}\end{array}$ & Entire & $\begin{array}{c}\text { Slightl } \\
y \\
\text { hairy }\end{array}$ & $\begin{array}{l}\text { Oppos } \\
\text { ite }\end{array}$ & $\begin{array}{l}\text { Petiola } \\
\text { te }\end{array}$ & Panicle & Nutlet \\
\hline
\end{tabular}

Table (3): Description of anatomical characters of all taxa studied

\begin{tabular}{|c|c|c|c|c|c|c|c|c|}
\hline \multirow{2}{*}{$\begin{array}{r}\text { Taxa } \\
\text { no. }\end{array}$} & \multirow[t]{2}{*}{ Plant species } & \multirow[t]{2}{*}{ Epidermis } & \multirow[t]{2}{*}{ Cuticle } & \multirow[t]{2}{*}{ Trichomes } & \multicolumn{2}{|c|}{$\begin{array}{c}\text { Mesophyll } \\
\text { (palisade tissue) }\end{array}$} & \multirow[t]{2}{*}{$\begin{array}{c}\text { Mechanical } \\
\text { tissue }\end{array}$} & \multirow[t]{2}{*}{ Crystals } \\
\hline & & & & & adaxile & abaxile & & \\
\hline 1 & $\begin{array}{c}\text { Cynanchum } \\
\text { acutum }\end{array}$ & $\begin{array}{c}\text { Small } \\
\text { uniseriate }\end{array}$ & Thick & Absent & $1-2$ & $1-2$ & collenchyma & Druses \\
\hline 2 & $\begin{array}{l}\text { Erodium } \\
\text { ciconium }\end{array}$ & $\begin{array}{c}\text { Small } \\
\text { uniseriate }\end{array}$ & Thick & $\begin{array}{l}\text { Unicellular } \\
\text { hair + } \\
\text { glandular hair }\end{array}$ & $2-3$ & ---- & collenchyma & Druses \\
\hline 3 & Plantago & Small & Thick & Glandular hair & 1 & 1 & collenchyma & Absent \\
\hline
\end{tabular}




\begin{tabular}{|c|c|c|c|c|c|c|c|c|}
\hline ovate & uniseriate & & & & & & \\
\hline 4 & $\begin{array}{c}\text { Rumex } \\
\text { vesicarius. }\end{array}$ & $\begin{array}{c}\text { Small } \\
\text { uniseriate }\end{array}$ & Thick & Glandular hair & $2-3$ & $2-3$ & collenchyma & Druses \\
\hline
\end{tabular}

Conclusions:

The recent study shed light on morphological and anatomical adaptation of studied plants to the arid environment. The results can be summarized as following:

1. Three species were annual except cynanchum acutum showed a perennial habit.

2. Plantago ovate and Rumex vesicarius had erect stem but Cynanchum acutum was climbing while Erodium ciconium was prostrate.

3. All species had uniseraite epidermis covered with thick cuticle.

4. Multilayer of palisade tissues found in all species except Plantago ovate.

5. Trichomes were absent in Cynanchum acutum and druses were absent in plantago ovate 


\section{References}

Abu Ziada, M.E.; Noor K. Al Kraeeshi and Maha Alshami. (2016). Ecological studies on wild medicinal plants in Egypt. III- Cynanchum acutum L. J. Plant Production, Mansoura Univ., Vol. 7 (1): 53- 60

Boulos, L. (1999). Flora of Egypt. vol.1: 30-34. Al Hadara Publishing Cairo, Egypt.

Boulos, L. (2000). Flora of Egypt. vol.Il: 220-222. Al Hadara Publishing Cairo, Egypt.

Boulos, L. (2002). Flora of Egypt. vol.III:108-120. Al Hadara Publishing Cairo, Egypt.

Cao, K.F. (2000). Leaf anatomy and chlorophyll content of 12 woody species in contrasting light conditions in a Bornean heath forest. Can. J. Bot., 78: 1245-1253.

Comus, P.W. and S.J. Phillips, (Eds.) (2009). A Natural History of the Sonoran Desert. Arizona-Sonora Desert Museum Press, Tucson and University of California Press, Berkeley.

Esau, K. (2013). Anatomy of Seed Plants. John Wiley and Sons, New York.

Fahn, A. (1990). Plant anatomy, 4th edition. Pergamon Press Ltd., Oxford.

Garces, J. (2013). Morpho- anatomical characterization of Allamanda cathartica (Apocynaceae) leaves, stem and roots. Ateneo de Manila University, Loyola Hights, Philippines.

Hameed, I., F. Hussain and G. Dastagir. (2008). Stomatal studies of some selected medicinal plants of Polygonaceae. Pakistan Journal of Botany, 40(6): 2273-2280.

Hameed, M., T. Nawaz, M. Ashraf, A. Tufail, H. Kanwal, M.S.A. Ahmad and I. Ahmad. (2012). Leaf anatomical adaptations of some halophytic and xerophytic sedges of the Punjab. Pak. J. Bot., 44: 159-164.

Hussain, A. Abulfatih. (2011). Ecological Anatomy of Xerophytic Leaves. University of Qatar, Faculty of Science, Department of Biological Sciences.

Johansen, D.A. (1940). Plant Microtechnique. McGraw-Hill Book Co., New York.

K. N. V. Rao, Sunitha Ch., David Banjii, Sandhya S. and Saikumar P. (2011). Pharmacognostic Studies on Rumex vesicarius. Asian Journal of Plant Science and Research, 1 (1):102-115.

Keshavarzi M., Najafian E., Nazem Bokaee Z. and Saifali M. (2016): Anatomical study of some Erodium (Geraniaceae) species in Iran. - Thaiszia - J. Bot. 26 (1): 11-20. - ISSN 12100420.

Marius-Nicugor Grigore and Constantin Toma (2008). Ecological anatomy investigations related to some halophyte species from Moldavia. ROM. J. BIOL. -PLANT BIOL., VOLUME 53, No 1, P. 23-30, BUCHAREST,

Metcalfe, C. R. and Chalk, L. (1979). Anatomy of the dicotyledons (1): 55, Clarenedon Press, Oxford. 
Pandey, B. P. (2010). A text book of botany Angiosperms. S. Chand and Company LTD. Ramnagar, New Delhi- 110055.

Parolin, P. (2009). Submerged in darkness: adaptations to prolonged submergence by woodyspecies of the Amazonian floodplains. Annals of Botany, 103(2): 359-376.

Pascedilla ca M . B.; Pallag A.; Gitea D.; Nemeth S. and Gavriş C (2016). Comparative histological analysis of some vegetal products obtained from Plantago L. genus. Analele Universităţii din Oradea, Fascicula Protecţia Mediului. Vol. XXVI

Täckholm, V. (1974). Students' flora of Egypt. 2nd ed. Cairo Univ. Publication, Corporative Printing Co., Beirut.

Wahid, A. (2003). Physiological significance of morpho-anatomical features of xerophytes. Journal of Biological Sciences, 2: 207-212. 


\section{الملخص باللغة العربية}

در اسات مورفولوجية وتثريحية على بعضانواع النباتات من ذوات القلقتين المجمعة من صحر اء شرق مصر أ.د/سحر عبد الفتاح عبد النتواب - أ.م.د// وفاء مرسى سعيد- د/ ريم محمد صلاح الدين سيد - م. فاطمة عبد النبى مرسى قسم النبات ـ كلية البنات للآداب و العلوم و التربية - جامعة عين شمس

Apocynaceae تمت الدراسة على اربعة نباتات برية تنتمى لاربعة عائلات من ذوات الفلقتين وهما العائلة الابوسينية

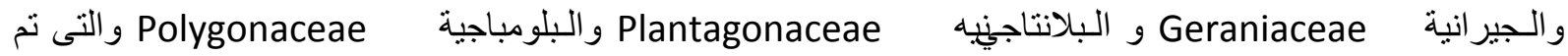

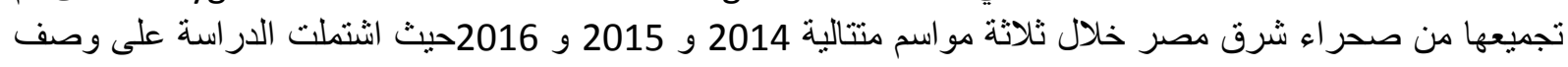

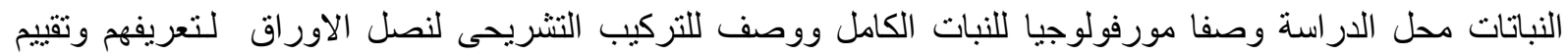

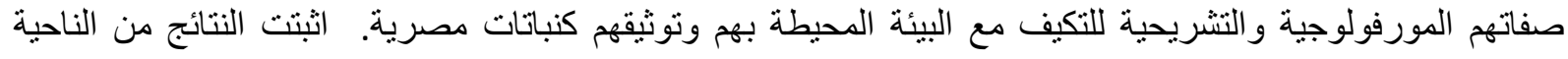

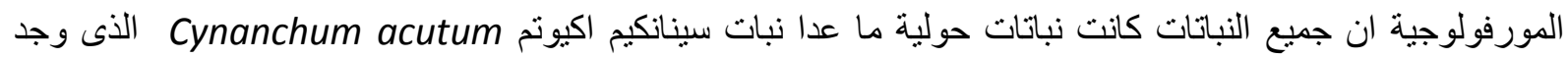

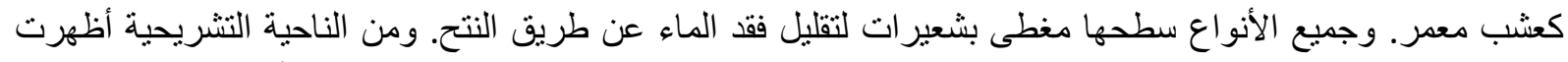

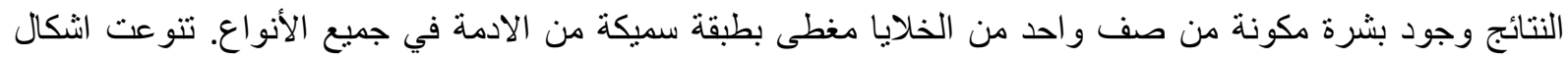

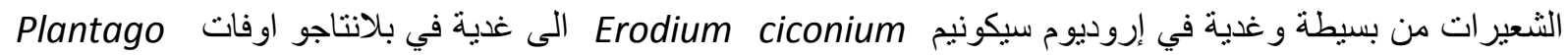

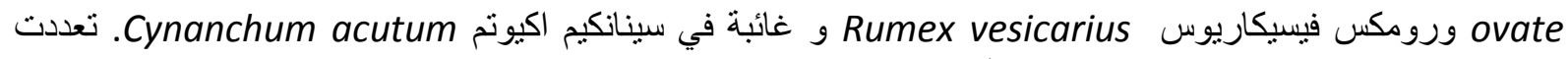
طبقات النسيج العمادى بالورقة في جميع الأنواع باستثناء سينانكيم اكيوتم

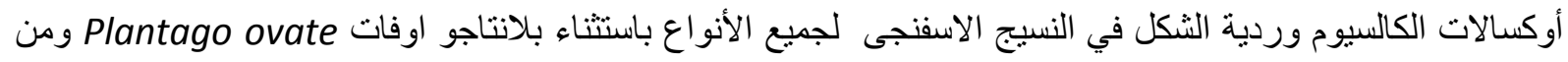
النتائج المذكورة أعلاه ثبت شكليا وتثريحيا ان جميع الأنو اع المدروسة قد تكيفت مع البيئة الصحر اوية المحيطة بهر. 